\title{
A Comparative Study of Contract Formation and Breach of Contract and Liability in China and Ohada (Note 1) Space Contract Laws
}

\author{
Moussa Sékou TRAORE (corresponding author) \\ School of Law, Wuhan University \\ Foreign Students Building 2-4-17, 430072 Wuhan, Hubei Province, China \\ E-mail: tmoussasekou@yahoo.fr \\ Yongping XIAO \\ Professor of Private International Law, Wuhan University Law School \\ Luojia Hill Wuchang, Wuhan, Hubei Province 430072, China \\ E-mail: ypxiao@vip.sina.com
}

Received: March 22, 2011

Accepted: April 20, 2011

doi:10.5539/jpl.v4n2p153

\begin{abstract}
Chinese politicians and businessmen and their African counterparts are improving economic and commercial relations between them. This manifest interest of partnership needs a legal framework which guarantees equal and fair advantages to both parties. To reach this global aim, China and Africa must develop their collaboration in the domain of law. In the 80s China has adopted laws to reflect the country's economic and social demands such as Economic Contract Law (1981), Foreign Economic Contract Law (1985), General Principles of Civil Law (1987). Now, to better facilitate economic growth the National People's Congress (NPC) has unified China's various national specialized contract laws to obtain the "Uniform" Contract Law 1999. OHADA is a system that aims the harmonization of business law in Africa. This study aims to compare the two systems contract formation, breach of contract and liability for breach in order to have a legal frame more appropriate for business between China and this part of African Continent.
\end{abstract}

Keywords: China contract law, OHADA contract law, French contract law, Contract formation, Breach of contract, Liability, Exemption

\section{Introduction}

China started a policy of expanded participation in the world political economy. This has been reaffirmed most recently with China's accession to the World Trade Organization. This process has resulted in increased interaction between regulatory norms and practices long-accepted as integral features of the People's Republic of China rule and foreign norms often associated with globalization that embody significantly different assumptions and expectations. China is stressing South-South cooperation and promotion of a new world order. In November 2006 China hosted the third Forum of China and Africa Cooperation (FOCAC) bringing together forty-eight African delegations and forty-one heads of state in the Chinese capital. Established in October 2000, the FOCAC brings together Chinese and African political and business leaders with the aim of "collective consultation and dialogue and a cooperation mechanism between the developing countries, which falls into the category of South-South cooperation.”(Note 2)

Nowadays, Chinese politicians and businessmen are more and more interested in the African continent. China's growing demand for raw materials has led it to closer involvement in the continent balancing its growing trade deficit with exports of commodities and labor. Such a policy has led China to massive investments in African natural resources, an increasing trade balance, renewed stress on development aid and ever growing amounts of Chinese exports to the continent. China pledged to increase its two-way trade with Africa from the current $\$ 40$ billion to $\$ 100$ billion by 2009, set up three to five special economic zones and institute a $\$ 5$ billion development fund to encourage Chinese investments in Africa.

As China-Africa economic relations are increasingly based on trade and investment, and trade is based on more than just commodities, the relationship is likely to expand along with economic growth in China and Africa. Economic relations are increasingly dominated by commercial ties rather than by aid considerations. The private sector rather 
than government ministries is increasingly the engine of economic exchange between China and Africa. This underscores the importance of improving the investment climate and strengthening the regulatory framework to achieve win-win outcomes. It further points to the importance of trade relationships and trade agreements.

Three decades ago Chinese leaders decided that legal modernization was necessary to promote economic modernization. Since that period China took its first step to develop a civil legal system to support a market-based economy by adopting laws to reflect the country's economic and social demands. In this regard, different laws were adopted such as Economic Contract Law (1981), Foreign Economic Contract Law (1985) and General Principles of Civil Law (1987). Now, to better facilitate economic growth, the National People's Congress has unified China's various national specialized contract laws to obtain the "Uniform" Contract Law 1999 (Note 3).

OHADA is a system of business laws and implementing institutions. Sixteen West and Central African nations (Note 4) adopted this regime in order to increase their attractiveness to foreign investment. In contract law OHADA state member's adopted on 22 March 2003 only "The Uniform Act on Contracts for the Carriage of Goods by Road". Other fields of contract law are governed by national laws. Because most of the member states are former French colonies, the OHADA laws are based on the French legal system.

Economic and commercial relations take form through contracts. These economic and commercial relations between China and Africa should take place in a good legal environment. The world of business needs a legal framework which allows it to grow and flourish easily and quickly. Thus a thorough study of the two contractual systems appears necessary to our eyes. This work focuses on contract formation (I) and breach of contract and

\section{Contract formation}

Article 2 of Chinese Contract Law (Note 5) defines a contract as an agreement between natural persons, legal persons or other organizations with equal standing, for the purpose of establishing, altering, or discharging a relationship of civil rights and obligations.

According to Art.1101 of French Civil Code (Note 6) (art.21 of Malian Régime Général des Obligations (Note 7), a contract is an agreement by which one or several persons bind themselves, toward one or several others, to do or not do something.

In the two definitions, we note that the contract is a manifestation of wills which connects one or more people, whether they are physicals or morals.

This manifestation of wills is complex and is made up of different steps.

\subsection{Accordance of minds:}

To make a contract it needs two concordant manifestations of will in their object and which are able to meet in time and space. The accordance of wills is fulfilled through an offer followed by an acceptance.

\subsubsection{Offer and acceptance}

The Contract Law is the first contract legislation in modern China that contains the provisions of offer and acceptance though those two terms were actually used in practice for many years before the Contract Law was adopted. Indeed, the concepts of both offer and acceptance are not originated in China but, as provided in the Contract Law, they necessarily reflect some Chinese characteristics. First of all, offer and acceptance are based on the premise that contract is a mutual agreement. Secondly, acceptance, if valid, will result in the conclusion of a contract and no consideration is needed. Thirdly, for certain contracts, their effectiveness would be subject to administrative approval after acceptance.

The Chinese New Contract Law promulgates a series of provisions on offer and acceptance. It considers that a contract is to be concluded by the exchange of an offer and an acceptance.

"An offer is a party's manifestation of its intention to enter into a contract with the other party, which shall (i) have terms that are specific and definite; and (ii) indicate that upon acceptance by the offeree, the offeror will be bound thereby.” (Note 8). Thus, there are two elements that an offer must contain: a manifestation of intent and desire to make a contract with others.

It distinguishes clearly an offer from an invitation to deal which is a party's manifestation of its intention to invite the other party to make an offer.

An offer becomes effective when it reaches the offeree. It can be withdrawn, revoked or terminated in conditions determined by law.

The concept of acceptance is provided in Article 21 of the Contract Law, which defines acceptance as "a manifestation of the offeree's assent to an offer". 
An acceptance shall be manifested by a notification thereof, except where it may be manifested by conduct. An acceptance shall reach the offeror within the time period prescribed in the offer. Where the offer does not specify a time period for its acceptance, the time when the acceptance must reach the offeror depends on whether or not the offer is made orally. Where the offer is oral, the acceptance shall be dispatched immediately, unless the parties have otherwise agreed; where the offer is not oral, the acceptance shall reach the offeror within a reasonable time. The time period for an acceptance of a written offer commences in accordance with how the written offer is made. Where an offer is made with a letter or telegram, the period for acceptance begins on the date shown on the letter or when the telegram is handed in for dispatch. If the letter does not specify any particular date, the period commences on the date of the postmark. Where the offer is made through an instantaneous communication, such as by telephone or facsimile, the period for its acceptance starts once it reaches the offeree. It becomes effective once the notice thereof reaches the offeror.

An acceptance can also be withdrawn but the notice of the withdrawal shall reach the offeror before or at the same time as the acceptance.

Article 1108 of French civil code (art. 28 of Malian RGO (Note 9) determines the essential conditions to the formation of contract.

According to French system of contract law (we remind that OHADA Law system is modeled on the French one), an offer to a contract is one which shows clearly the intention of the offeror to enter into a binding contract on the terms set out. It contains the essential elements of the contract, whose acceptance without reserve by the other party creates the contract (Note 10).

It is distinguishable from a letter of intent or offer to start negotiating, which may create only an obligation to negotiate in good faith and therefore possibly give rise to a quasi-delictual liability if the negotiations are not made in good faith or arbitrary ended.

An offer may be inferred from conduct (displaying goods with their prices usually constitutes an offer for sale; a taxi waiting at a taxi rank thereby offers a contracts of carriage). An offer may be to the general public or a particular individual. It may also be for a certain time. If it is opened for a certain time, it cannot be revoked before the end of that time. Revocation of an offer before the definite time usually gives rise to quasi-delictual liability in damages. An offer to indefinite time can be revoked at any time if made to the general public or within a reasonable time if made to a given individual.

Acceptance must be of the offer as a whole. Reservations or modifications of the terms of offer constitute counter-offer. Generally, mere silence does not constitute acceptance but there are many possible exceptions. Acceptance may be implicit, as where the terms of offer where fulfilled or there is a continuing business relationship between the parties and the proposed contract is of the kind regularly implemented between them. Trade usages may also indicate acceptance despite the absence of any response to an offer (Note 11).

\subsubsection{Place and time of formation}

A very common notion under the Contract Law is that the conclusion of a contract is dependent on the effectiveness of the acceptance.

According to Article 25 of Contract Law of China, a contract is concluded when acceptance becomes effective. In light of the Contract Law, the conclusion of contract means that the parties have reached a mutual assent which demonstrates that the parties have agreed on the terms and conditions of the contract. The conclusion of the contract may also serve as an indicator of the beginning of the contractual rights and obligations between the parties. Basically there are two factors that affect the effectiveness of acceptance. These two factors are the time and place.

In an attempt to clearly address the time of contract, the Contract Law focuses on the way in which a contract is concluded. In addition to Article 26 that provides the "arrival rule" for acceptance to take effect, Article 32 further stipulates that when a contract is made in writing the contract is concluded at the time both parties sign or affix a seal on it (Note 12). Although Article 32 does not specify which one controls if the signature and seal are made at different times, the general rule is the doctrine of "first in time". Moreover, under Article 33, if the contract is concluded in the form of a letter or data-telex, etc., a party may request to sign a letter of confirmation (Note 13). Under this circumstance, the contract is concluded when the confirmation letter is signed.

With regard to the place of conclusion of contract, it is provided in a more specific way in the Contract Law because the place of conclusion of contract is regarded as an essential element that would affect the matters of jurisdiction (and choice of law in foreign cases) concerning the contract disputes. First of all, Article 34 adopts a general principle that the place where the acceptance takes effect is the place of conclusion of contract. Secondly, Article 34 contains a special provision stating that when the contract is concluded in the form of data-telex, the main business 
place of the recipient shall be the place of conclusion of contract, and if there is no main business place the recipient's habitual residence shall be considered as the place of conclusion of contract. Article 34 also permits the choice made by the parties if the parties have agreed otherwise as to the place of conclusion of contract (Note 14). And thirdly, in accordance with Article 35, if the contract is made in writing, the place where both parties sign or affix a seal shall be the place where the contract is concluded.

It is interesting to note that although the Contact Law is not the first contract legislation in the modern China, it is the first time that offer and acceptance are provided in the law. However, it is important to remind that for certain types of contracts in China government approval is required, and in these cases, the contract, though being formed, would not take effect prior to obtaining the approval from the government. Article 44 of the Contract Law contains the provisions that specifically deal with the formation and legal effect of a contract. According to Article 44, a contract legally formed shall take effect upon the formation of the contract. But if government approval or registration is required, the contract will become effective only after the completion of the approval or registration (Note 15).

In French, as in OHADA's countries contract legislations, a contract is formed by the conjunction of offer and acceptance. The difficulty that appears here is about the time and the place of formation of the contract. Here, we must distinguish whether parties to the contract are present or not.

No problem arises when the offeror and the offeree are in the presence of each other. The principle is that the contract is formed instantly. The accordance of wills is fulfilled immediately; offer being seized by acceptance, the contract is entirely and definitely formed.

As regards the case where the two parties are absent, the question whether a contract is formed when acceptance is posted or when the offeror receive it has occupied the courts. The issue is still treated case by case, although the courts tend generally to hold that acceptance is given, and thus the contract formed, when it is posted (Note 16).

\subsection{Contract validity}

A contract that is formed in accordance with the law becomes valid or effective immediately upon its formation. However, where a law or administrative regulation requires approval or registration, a contract shall take effect only upon its successful completion of such procedure.

A formed contract may not be necessarily valid.

\subsubsection{Void contracts}

A contract shall not be enforced if it is void and its voidness retroactively applies to the date the contract was made. A well-accepted principle is the maxim that a contract that is void now is void from its beginning. Generally speaking, a void contract is the contract that is concluded but violates the law or regulations or does not meet the requirements for the contract to become effective. Therefore, if a contract becomes void, it has no legal effect and of course is not binding. Based on this principle, Article 56 of the Contract Law explicitly provides that a contract that is null and void shall have no legally binding force from the very beginning.

In this situation, the expression of the will of the parties cannot create a contract that has the validity of a juristic act. Article 58 of China's General Principles of Civil Law, similar to article 52 of China's Contract Law, identifies several kinds of void contracts:

1. Contracts concluded by a person who lacks the capacity to perform civil acts;

2. Contracts concluded by a person with limited capacity to perform civil acts that, according to the law, cannot be concluded by such a person;

3. Contracts formed as the result of fraud or duress, or when one party takes advantage of a person;

4. Contracts related to a malicious conspiracy of the parties;

5. Contracts that violate the law or the social or public interest;

6. Contracts that violate mandatory state plans; and

7. Contracts that employ a legal form to conceal an illegal purpose (Note 17).

Article 1108 of French Civil Code, similar to article 28 of Malian RGO, determines the structure of contract. French law considers a contract illegal (void) because its cause or reasons are illegal, as when its purpose is to evade a mandatory provision such as the prohibition of preferred payments by an insolvent debtor. A lawful cause being a condition of the formation of the contract, the contract is automatically void. The same rule applies to the object of the contract (absolute voidness). So a transaction relating to an estate which the contracting party expects to inherit is void because its object is unlawful. 
Illegality may also arise from the consequences of the contract; for example, a contract whereby the president of a company transfers corporate assets to another company in which he has personal interests, or a contract made in breach of exchange control regulations. Whether such contracts are voidable is determined either in the relevant statutory provision or by courts on a case-by-case basis. The general principle is that there is no nullity without specific legal provision. So the courts usually held that contracts in breach of exchange control regulations, then in force, were valid, subject to the application of the specific penalties provided for in such regulations. In the field of economic public policy and consumer protection, however, there is a tendency to make nullity a specific sanction.

\subsubsection{Voidable contracts}

It must be kept in mind that under the Contract Law, a contract will be void if there is a fraud or duress that has caused harm to the State interest. If, however, no State interest is involved, the fraud or duress will only render the contract voidable. Once again, the underlying premise is the supremacy of the State interest in Chinese economy. As far as the contract is concerned, the major difference between void contract and voidable contract is that when a contract is void, it will take no effect without any action of the parties, but if a contract is voidable, the party seeking to avoid the contract must make a request.

In accordance with Article 54 of the Contract Law, if a contract is concluded by a party against the other party's true intention through the use of fraud, coercion or exploitation of the other party's unfavorable position, the injured party shall have the right to request the people's court or an arbitration body to modify or rescind the contract. Article 54 also provides that a party shall have the right to modify or rescind a contract if the contract is concluded as a result of a material misunderstanding or is obviously unfair at the time of contract.

According to article 1116 of French Civil Code (art. 38 of Malian RGO), a contract is voidable where one party's intentional deceptive conduct (dol) has prompt the other party to contract. The principle is similar to that of fraudulent misrepresentation, but somewhat wider because French law does not require a false misleading statement of fact. Silence may constitute dol when one contracting party had a duty of disclosure, express or implicit. As in French Civil Code (art. 1112), countries of OHADA's area legislation also recognize violence as a reason to make a contract voidable (relative nullity). The question is whether a reasonable person would feel that this person or possessions were threatened by some real and present harm. The court takes due regard to the age, sex and circumstances of the parties. The pressures exerted may be either physical or moral, but must be essentially unjust and illegal to fall within rule.

\section{Breach of contract and liability}

In contract law, the breach of a contract occurs where there is an anticipated repudiation or an actual breach. The anticipatory repudiation is a concept borrowed into the Chinese Contract Law from the common law system.

The parties to a contract that is legally enforceable are obligated to perform the obligations arising from the contract, and failure to perform may constitute a breach of the contract for which the party in breach will be held liable. In accordance with the concept of anticipatory breach, a party does not have to wait until after the time of performance in order to hold the other party liable for its breach, provided, however, that the other party has expressly stated or indicated by its conduct that it will not render its performance (Note 18).

\subsection{Liability for breach}

Generally, the liability for breach is defined as the civil liability that arises from the conduct of violation of a contract.

There are two notable principles governing liability for breach that have fundamental impacts on Chinese contract law in the remedies. The first is the principle of liability. Under this principle, a person will be legally liable for failure to fulfill what he is obliged to do as required by law. The best example to illustrate this principle is Article 106 of the 1986 Civil Code. It is provided that a citizen or legal person who breaches a contract or fail to fulfill other obligations shall bear civil liability. Obviously, Article 106 attempts to differentiate civil liability from obligation. Scholars have also made efforts to make distinction between liability and obligation. In one book, obligation is defined as the commitment that a party is required to make either under the provision of law or by a contract, and the liability is termed as the consequence in which the party is compelled to continue performing or to take other remedial acts when the party fails to fulfill his obligation (Note 19). Therefore, the liability is not simply the obligation, but the legal consequence facing the obligor in case the obligor defaults (Note 20).

The second principle is the doctrine of liability imputation. Liability imputation is the process of determining whether the party in breach shall be responsible for the breach of the contract. If a party is alleged to have breached a contract, before any liability is to be imposed, the question that must first be answered is whether the breach is caused by the party. The next question then will be whether the liability shall be imposed on the party who is found 
to be in breach. The liability imputation principle requires that the civil liability be imposed for what should be legally blamed. This principle is deemed as the cornerstone of determination of civil liabilities because it establishes standards and rules under which the determination shall be made.

In contract law theory, two basic approaches are commonly employed as the standards to impute civil liabilities, namely the fault approach and strict liability (or no fault) approach.

Liability for breach is provided by article 1382 et seq. of French Civil Code. According to article 1382, "Any act whatever of man, which causes damage to another, obliges the one by whose fault it occurred, to compensate it." The same provision is stipulated by article 125 of Malian RGO.

French Contract Law links liability exclusively to a fault. But they are some decisions and regulatory provisions which are equivalent in effect to strict liability.

\subsubsection{Fault}

As in civil law tradition, fault was an essential component in determining breach in Chinese contract law.

The fault approach suggests that a party who fails to perform the contract should not be responsible for damages unless he is found at fault. Thus under the fault approach, the liability of the party who breaches the contract will be determined in consideration of both the conduct of breach and underlying fault of the party. This view of monism of the principle of attributing contractual liability is widely acknowledged by the academic. The obligor is at fault for not carrying out his obligations and this is a pre-requisite condition for bearing liability for the breach of contract (Note 21). Due to the special nature of contractual liability, the monism of the principle of attributing liability and the principle of fault liability in contractual liability is the principle of fault deduction (Note 22).

If fault is not now an essential component to determine breach in China, it is still the main substance of liability in French and OHADA systems of law.

French Civil Code in its art. 1603 provides that the vendor has two main obligations: "to deliver and to warrant the thing which is sold". Under Article 1604 et seq. relating to delivery obligations, the courts have laid down the principle that the vendor must deliver a thing whose characteristics correspond to the request of the purchaser. In the case of default in conformity the sale can be rescinded. Article 1641, on the other hand, provides "the seller is bound to guarantee the goods against hidden defects which make them unfit for the use for which they are intended or which so impair such use that the purchaser would not have bought them, or would have bought them at a lower price, if he had known of such hidden defects". The distinction between actions arising from hidden defects and actions for non-conformity has become of major importance in the French law of sales because of the different procedures they involve. An action based on hidden defects in the goods can be started at any time after delivery, provided that it is started within a short period of time after the disclosure of the hidden defects. An action in conformity, however, is not subject to the short period of time requirement; but cannot be started if the goods were accepted without reserve at the time of delivery. In addition, a purchaser starting an action on grounds of hidden effects can take such action either against his seller or by action against any previous seller, up to the manufacturer, despite the absence of a contractual relationship between them. This is because Article 1641 creates a warranty obligation, the benefit of which is transferred by subrogation to each successive buyer. Although the grounds for the two actions are different, they may well overlap, and both are usually started together by dissatisfied purchasers. The distinction between the actions is much criticized because of the practical difficulty of distinguishing between hidden defects and faults in conformity.

\subsubsection{Strict liability}

Strict Liability is a notion introduced into Chinese Contract Law from the Anglo-Saxon Law. The strict liability or no fault doctrine, on the contrary, allows a party to claim damages if the other party fails to fulfill his contractual obligations regardless of the fault of the failing party. Pursuant to the strict liability doctrine, if the performance of a contract is due, any non-performance will constitute a breach and the fault on the party in breach is irrelevant. Strict liability has obvious and easily identifiable advantages (Note 23). Firstly, the plaintiff need only prove to the court the fact that the defendant did not carry out his contractual obligations. The plaintiff is not required to prove that the defendant was at fault. Strict liability also does not require the defendant to prove that he was not at fault for not performing. Thus, the difficulty of proving whether there is fault is done away with and judgment is also facilitated. It is also beneficial to the economy of the proceedings. Secondly, there is a direct relationship between the liability for non-performance and breach of contract as there is a causal link between the both of them. Strict liability helps in ensuring that the parties treat the contract seriously and it also adds to the gravity of the contract. The tendency of the party in breach to try and argue that there was no fault, hoping to escape liability and to avoid being under the principle of fault liability helps in strengthening the spirit of responsibility and the legal awareness of the parties 
(Note 24).

Strict liability is not expressly stipulated in French contract law and similar. Despite this lack of such provision in French contract law, some decisions and statutory or regulatory provisions create obligations for suppliers of goods or services equivalent in effect to strict liability. The obligations of suppliers of goods and services have been steadily extended in the field of contract throughout the century, in order to make available to contracting parties remedies which were not practicable under tort law because of the requirement of fault under Article 1382. A landmark decision held that "the carrying out of the contract of carriage implies ... for the carrier an obligation to carry the passengers safely to their destination” (Note 25) - thus permitting the passengers to start their action on the basis of the contract simply by showing that this obligation of safety had not been complied with, and without needing to show distinct fault as required by Article 1382.

\subsection{Exemption of liability}

A contract is based on the traditional doctrine of pacta sunt servanda (agreement must be kept). A party who fails to perform a contract shall be held liable for breach. But such liability may be excused in certain circumstances that are either agreed by the parties or provided by the law. If a party is exculpated from the liability for breach under the agreed circumstances, the exculpation is called contractual exemption. When the liability for breach is excused under the provision of law, the exculpation is termed as legal exemption. If the breach falls within the legal exemption, the liability of the party in breach will be excused as the operation of law without reference to the agreement of the parties or the terms of the contract.

\subsubsection{Force majeure}

The only legal exemption of the contractual liability in the Contract Law is the exemption on the ground of force majeure. Under Article 117 of the Contract Law, in case where a contract could not be performed because of force majeure, the liability for breach shall be excused in part or wholly in light of the effects of the force majeure. Recall that in Article 94 of the Contract Law, the force majeure is a legal ground on which a contract may be dissolved. Here upon occurrence of force majeure, a party's obligation to perform the contract will be excused and the liability for breach will consequently be exempted.

In the meantime, Article 117 provides two exceptions to the legal exemption, namely exemption from the liability due to force majeure, under the Contract Law. The first exception is where "the law otherwise provides". For example, under Article 34 of the Post Law, force majeure may not exempt the liability of the post office for the loss of money remittance or insured postal articles. The second exception involves delayed performance. It is provided in Article 117 of the Contract Law that if the force majeure occurs after one party has delayed in performance the liability shall not be exempted. The underlying reason is that delay in performance is a breach for which the nonperforming party should be held liable, and force majeure should not exempt the liability of the party who is already in breach.

Force majeure in the PCR closely follow the French or continental choice of language.

The principle of force majeure is provided by article 1148 of French Civil Code (art. 120 of Malian RGO). It stipulates that "there is no occasion for any damages where a debtor was prevented from transferring or from doing that to which he was bound, or did what was forbidden to him, by reason of force majeure or of a fortuitous event" (Note 26).

Force majeure, connoting superior or irresistible force that excuses non-performance or delayed performance, is a term incorporated directly form French into international and Anglo-American contract law. In its narrow sense, force majeure is limited to calamities of unavoidable force arising from causes wholly independent of human intervention.

The concept of force majeure would have very limited application in contract law with its scope so narrowly restricted. In fact, however, the reach of force majeure has undergone significant expansion in many countries as the result of consensual bargaining on contractual terms by the parties, and also has developed extra-contractually through the evolution of judicial doctrine and statutory language.

\subsubsection{Other causes of exemption of liability}

Chinese contract law allows parties to a contract to negotiate in their contract a force majeure clause (contractual exemption) in order to better protect their respective interests. But absence of the force majeure clause does not deprive a party of the right to claim exemption upon occurrence of force majeure because of the availability of Article 117 legal exemption. But, if there is a force majeure clause in the contract, the clause will be regarded as a supplement to the legal exemption and may be used to help allocate risks and ascertain the scope or coverage of the 
force majeure.

In the French contract law, as in OHADA's space contract law, in addition to the contractual exemption, there are also other causes of exemption from liability.

These causes are related to the act of the creditor or a third party.

Article 121 of Malian RGO stipulates that the fault of the victim reduces the liability of the author of the damage when it has contributed to the result.

It follows from this that the act of the creditor, or not at fault, exonerates completely the debtor when it was the sole cause of damage; but if the debtor has concurred by its fact to the achievement of the damage, then there is a partial exemption of the debtor and sharing responsibility.

The debtor is also exempt if the failure is due to a third party. But to be discharged this must be irresistible and unforeseeable, therefore present the characteristic of force majeure for the debtor. This fact should not come from an employee of the debtor or any person under his responsibility.Conclusion

The past decade has witnessed a major and very significant increase in China's engagement in Africa. FOCAC was established, and is now running, as the main means by which to conduct dialogue between different African nations and China over where the general direction of this relationship should go. More importantly, it provides an integrative framework for treating Africa as a single actor, which will greatly promote the identity-building of Africa and differentiate itself with other relationship. The FOCAC process offers Africa a new opportunity for a partnership with China and the prospect of a long-term mutually beneficial relationship with the world's fastest-growing economy.

It is evident from this brief comparison between the new Chinese Contract Law and the contract law of OHADA area that both contract laws have assimilated many of the general rules set forth by the UNIDROIT Principles. Chinese new contract law has adopted many rules of UNIDROIT Principles. Of these many are new to the Chinese contract system. The OHADA area contract law is based on French contract law. Most of these countries are France ancient colonies. The comparison of these two contract laws shows the similarities and differences between them. That is important in the future harmonization of a legal framework of commercial and economic cooperation of China with Africa.

\section{References}

Abdoulaye Garba Tapo. (1996). Cours de droit des obligations, Edition Jamana.

Claire Moore Dickerson. (2005). Harmonizing Business Laws in Africa: OHADA calls the tune. Columbia Journal of Transnational Law.

C. Stephen Hsu. (2007). Contract Law of the People's Republic of China. Minnesota Journal of International Law. Donald L. Grace. (2001). Force Majeure, China \& the CISG: Is China's New Contract Law a step in the right direction? San Diego international Law journal.

Gerald Schmitt. (2007). Is Africa turning east? China's new engagement in Africa and its implications on the macro-economic situation, the business environment and the private sector in Africa.GTZ.

Jean Carbonnier. (1993). Droit Civil Tome 4 Les Obligation, (17 ed.) Paris: PUF.

John Gregory. (2000). Uniform Contract Law of the People’s Republic of China: First comparative look. Florida Journal of International Law.

Lester Ross. (1991). Force Majeure and the related doctrines of excuse in contract law of the People's Republic of China. Journal of Chinese Law.

Martor Boris, Pilkington Nanette, Sellers David S., Thouvenot Sébastien. (2002). Business Law in Africa: OHADA and the Harmonization Process, $\left(2^{\text {nd }}\right.$ ed.). GMB.

Mo Zhang. (2006). Chinese Contract Law, Theory and Practice, Martinus Nijhoff Publishers, Leiden. Doi:10.1163/ej.9789004150416.i-372, http://dx.doi.org/10.1163/ej.9789004150416.i-372

Michal Meidan. (2006). China’s Africa Policy: Business now, Politics later. Asian Perpective, Vol.30.

Shelton Garth and Paruk Farhana. (2008). The Forum on China-Africa Cooperation: A Strategic Opportunity, Johannesburg: Institute for Security Studies, South Africa.

ZHENG Yunrui. (2003). Perspectives of Contemporary Legal Developments in Chinese Law, Studies on Certain Issues of the General Principles of contract Law. Singapore Journal of International and Comparative Law.

\section{Legislation}


Code Civil Français, Edition 2010.

Contract Law of the People's Republic of China, 1999.

Loi N`87 - 31/AN-RM du 29 août 1987 fixant le Régime Général des obligations au Mali.

Economic Contract Law of China, 1981.

Foreign Economic Contract Law of China, 1985.

China's General Principles of Civil Law, 1987.

\section{Notes}

Note 1. OHADA: Organisation pour l'Harmonisation du Droit des Affaires en Afrique (in English, Organisation for Harmonisation in Africa of Business Laws).

Note 2. Characteristics of Forum on China-Africa Cooperation from the website of the Chinese Ministry of Foreign Affairs. [Online] Available: http:// www.fmprc.gov.cn/zflt/eng/gylt/ltjj/t157576.htm

Note 3. Contract Law of China (hereinafter).

Note 4. OHADA members are: Benin, Burkina Faso, Cameroon, Central Africa Republic, Comoros, Congo, Ivory Coast, Gabon, Guinea, Bissau Guinea, Equatorial Guinea, Mali, Niger, Senegal, Chad and Togo.

Note 5. See Contract Law of China, art. 2.

Note 6. See the French Civil Code, art. 1108.

Note 7. RGO (hereinafter).

Note 8. See Contract Law of China, art. 14

Note 9. See RGO, art.28.

Note 10. Com. 6 mars 1990.

Note 11. Com. 21 may 1951.

Note 12. See Contract Law of China, art. 29.

Note 13. See id., art. 33.

Note 14. See id., art. 34.

Note 15. See id., art. 44.

Note 16. Com. 7 January 1981.

Note 17. See General Principles of Civil Law of China, art. 58; see also Contract Law of PRC, art. 52.

Note 18. See Contract Law of China, art. 108.

Note 19. See Xing Ying, Liabilities for Breach of Contract, 4 (China Legal System Press, 1999).

Note 20. See Cui Jianyuan, Studies on Contractual Liabilities, 3 (Ji Lin People’s Publishing House, 1992).

Note 21. See Xie Bang Yu, Min Shi Ze Ren: Civil Liability (Law Press, 1991) at 107.

Note 22. See Wang Jia Fu, He Tong Fa: Contract Law (China Social Sciences Press, 1986) at 481.

Note 23. Strict liability is the direction of development in contract laws. Two major legal systems have adopted different principles in attributing liability with regards to breach of contract. The Chinese legal system has adopted the principle of fault liability with regards to most contractual liability while Anglo-American system has adopted the principle of strict liability.

From the perspective of the relevant legislature of China, the General Principles of Civil Law and the Foreign Economic Law has adopted the principle of strict liability, but the Economic Contract Law adopts the principle of fault liability.

Note 24. See Cui Jian Yuan, Hai Xia Liang An He Tong Ze Ren Zhi Du De Bi Jiao Yan Jiu: The Comparative Research of the Regime of Contractual Liability in China and Taïwan (Student Paper of University of Qinghua, 2000) Vol. 2.

Note 25. Civ. 21 November 1911.

Note 26. See the French Civil Code, art. 1148. 